\title{
Biochemical analysis of some serum trace elements in donkeys and horses in Eastern region of Kingdom of Saudi Arabia
}

\author{
Turke Shawaf $^{1}$, Faisal Almathen², Ahmad Meligy ${ }^{1,3}$, Wael El-Deeb ${ }^{1,4}$ and Shahab Al-Bulushi ${ }^{1}$
}

1. Department of Clinical Studies, College of Veterinary Medicine, King Faisal University, 400 Al-Hasa, 31982, Saudi Arabia; 2. Department of Veterinary Public Health and Animal Husbandry, College of Veterinary Medicine, King Faisal University, 400 Al-Hasa, 31982, Saudi Arabia; 3. Department of Physiology, Agricultural Research Center, Egypt; 4. Department of Veterinary Medicine, Infectious Diseases and Fish Diseases, Faculty of Veterinary Medicine, Mansoura University, Mansoura, Egypt.

Corresponding author: Shahab Al-bulushi, e-mail: shdx.2009@gmail.com

Co-authors: TS: tshawaf@kfu.edu.sa,FA: falmathen@kfu.edu.sa, AM: amelegi@kfu.edu.sa, WE: drwaeleldeeb@yahoo.com Received: 04-07-2017, Accepted: 29-09-2017, Published online: 25-10-2017

doi: 10.14202/vetworld.2017.1269-1274 How to cite this article: Shawaf T, Almathen F, Meligy A, El-Deeb W, Al-Bulushi S (2017) Biochemical analysis of some serum trace elements in donkeys and horses in Eastern region of Kingdom of Saudi Arabia, Veterinary World, 10(10): 1269-1274.

\begin{abstract}
Aim: Little is known about the serum levels of trace elements in donkeys and horses in Saudi Arabia. This study aimed to investigate the levels of some trace elements in these two species in the eastern region of Saudi Arabia and to compare the obtained results with the reference values.

Materials and Methods: Seventeen Arabian horses and twenty eight Hassawi donkeys were randomly selected for this study. All of the studied healthy animals were kept under a uniform feeding protocol without any minerals supplementations. Atomic absorption spectrometer is used to estimate the serum concentrations of selenium (Se), manganese (Mn), chromium $(\mathrm{Cr})$, copper $(\mathrm{Cu})$, iron $(\mathrm{Fe})$, and zinc $(\mathrm{Zn})$ in the analyzed samples.
\end{abstract}

Results: Significant differences between horses and donkeys were observed in three of the studied elements ( $\mathrm{Se}, \mathrm{Mn}$, and $\mathrm{Cr}$ ). Statistically significant differences were found in serum Se and $\mathrm{Cr}$ between male and female horses. The male donkey showed higher $\mathrm{Mn}, \mathrm{Cu}$, and $\mathrm{Zn}$ levels than female animals.

Conclusion: The obtained results of trace element levels in serum of Hassawi donkeys and Arabian horses in Saudi Arabia are considered as the first values to be published for these breeds. When compared to other animals, the measured amounts of $\mathrm{Se}, \mathrm{Mn}, \mathrm{Cr}, \mathrm{Cu}, \mathrm{Fe}$, and $\mathrm{Zn}$ in the serum of horses and donkey are often differed, possibly because of the varying living or feeding conditions. Moreover, there were some differences in some of the trace elements concentrations related to animal's gender and species (horses and donkeys), which will be considered in the interpretation of the laboratory data.

Keywords: donkey, horse, serum, trace elements.

\section{Introduction}

Minerals play an essential role as structural components of the body and in the activities of enzymes and hormones. They are also considered as important constituents of body fluids and tissues and as regulators of cell replication and its differentiation [1]. Minerals are important for all of the physiological processes in animals body [2]. The micro or trace minerals are required by the body in $<100 \mathrm{ppm}$ in the diet, and these elements include copper $(\mathrm{Cu})$, chromium $(\mathrm{Cr})$, iron $(\mathrm{Fe})$, manganese $(\mathrm{Mn})$, selenium $(\mathrm{Se})$, and zinc $(\mathrm{Zn})$ [1]. As trace elements are found in the body in low concentrations, any increase or the decrease in their concentrations will be harmful [3]. Trace elements disorders considered as one of the commonly diagnosed problems [4]. However,

Copyright: Shawaf, et al. Open Access. This article is distributed under the terms of the Creative Commons Attribution 4.0 International License (http://creativecommons.org/licenses/ by/4.0/), which permits unrestricted use, distribution, and reproduction in any medium, provided you give appropriate credit to the original author(s) and the source, provide a link to the Creative Commons license, and indicate if changes were made. The Creative Commons Public Domain Dedication waiver (http:// creativecommons.org/publicdomain/zero/1.0/) applies to the data made available in this article, unless otherwise stated. sometimes trace elements deficiencies can occur without any clinical signs [3]. The clinical interest in trace elements determination for the diagnosis of different diseases has increased in the recent years. Trace elements metabolism may be concerned with the intake, dietary availability, distribution, absorption, excretion, mobilization, storage, and biochemical activity [5]. Results of most trace elements levels for plasma and serum have been assumed to be the similar [6]. Blood is the biological material that is mostly used for the analyses of trace elements due to the level of macro- and micro-elements in the serum which reflects their content in the body $[7,8]$. Se, has an important role as an antioxidant which is traditionally considered and supplemental Se may have a protective role in animals [9]. It is also considered as a cofactor in metalloenzymes such as glutathione peroxidase. Furthermore, there is some evidence that Se has a role in the immune responses [10]. Mn has an important role in fats and carbohydrates metabolization and also it is important for cartilage formation by playing a role in the synthesis of chondroitin sulfate. $\mathrm{Cr}$ is considered as a biosynthesis of glucose tolerance factor. Its deficiency causes impairment of glucose tolerance while the toxicity results in renal failure 
and dermatitis [11]. $\mathrm{Cu}$ is considered as a cofactor for many different enzymes and as a structural component of other proteins which are important for the immune reactions [12]. Fe is considered as the highest numerous trace elements. It is necessary for electron transfer reactions, cell growth and oxygen binding and transportation [13]. Any decrease or increase in Fe concentrations can cause disturbances in the immune system that is why it is important to maintain its amount in the body [14]. $\mathrm{Zn}$ is essential for the regulation of gene expression because it is found in the nucleus of the cells and in some of cell proteins [15]. $\mathrm{Zn}$ is a trace element that must be supplied through diet [9]. Severe Zn deficiency can lead to physical growth impairments because of the different organ systems that are affected by its deficiency [16,17].

In Saudi Arabia, there are many breeds of donkeys in which the Hassawi breed is considered as one of the most common breeds that are used by the native people [18]. Recently, the horses and donkeys race events and the medical care for these animals increased dramatically [18]. Due to the limitation in the data that are available regarding $\mathrm{Se}, \mathrm{Mn}, \mathrm{Cr}, \mathrm{Cu}$, $\mathrm{Fe}$, and $\mathrm{Zn}$ concentrations in horses and donkeys, further studies are needed to determine the reference values for these species [19].

The determination of trace elements profile is also important to obtain the necessary information regarding animal's health and also the determination of the increase or decrease in these parameters will be useful in the diagnosis and for the appropriate treatment selection [20,21]. As little is known about the concentration of trace elements in donkeys and horses in Saudi Arabia, this study aimed to investigate the levels of some trace elements in these two species in the eastern region of Saudi Arabia and to compare the obtained results with the reference values.

\section{Materials and Methods}

Ethical approval

The study was approved for research purpose by the Ethics Committee at King Faisal University in Saudi Arabia.

\section{Animals}

A total of 45 randomly selected physically fit and clinically healthy animals including 17 pure Arabian horses (10 females and 7 males) ranged from 4 to 7 years of age, and their body weight ranged from 280 to $435 \mathrm{~kg}$ and 28 Hassawi donkeys (16 of them were females and 12 males) their age ranged from 5 to 14 years and their weight ranged from 145 to $270 \mathrm{~kg}$ were studied. Before blood collection, the animals were examined physically and clinically to ensure that they are free from any apparent disorders. All of the studied animals were kept under a uniform feeding protocol in which they were fed on pastures, grains such as barley, oat, and corn and concentrate cubes without any minerals supplementations.

\section{Sample collection}

The blood samples were drawn from the jugular vein of all of the 45 studied animals between April and May 2016 at the early morning into sterilized vacutainer plastic blood collection tubes (Guangzhou Improve Medical, China). Centrifugation at $1500 \times g$ for $20 \mathrm{~min}$ is used to separate the plasma, and it was collected in a sterile vial to be preserved at $-20^{\circ} \mathrm{C}$ until the trace element analysis were carried out.

\section{Estimation of serum trace elements}

Concentrations of $\mathrm{Se}, \mathrm{Mn}, \mathrm{Cr}, \mathrm{Cu}, \mathrm{Fe}$, and $\mathrm{Zn}$ were estimated in all of the serum samples using a Shimadzu AAS 6800 atomic absorption spectrometer (Japan). Flame atomic absorption spectrometry (FAAS) supplied by heated graphite atomizer system as well as deuterium set corrected used in the research. Furthermore, the FAAS, an air/acetylene gas (10:1.5) was used. Flame atomic absorption was used for the analysis of $\mathrm{Cu}, \mathrm{Fe}, \mathrm{Mn}$, and $\mathrm{Cr}$. However, Se analysis was performed using Graphite furnace atomic absorption spectrometry (GFAAS) through argon being as an inert gas. Samples are injected to the GFAAS and FAAS through Shimadzu ASO-6100 automatic sampler. Mars_Xpress (CEM-USA) Microwave Digestion System was used. All of the digestion procedures were done using Teflon reaction vessels. $5 \mathrm{~mL}$ of concentrated nitric acid was used for washing the vessels before each digestion process. Samples quantitative analysis was performed by external calibration. Standard solutions were prepared from 19.6\% (w/w) $\mathrm{HNO}_{3}$ (like the acidic concentrations in the prepared sample). Eight concentrations in the linear dynamic variety were measured. Calibration curve to each analyst was plotted from the limits of detection. To avoid any errors, a slight instrumental drift is monitored by analyzing calibration standards at regular intervals during analysis alongside samples were taken into account. Full quantitative analysis mode was applied for all of the measurements. For digestion, $0.5 \mathrm{~g}$ of each serum sample in triplicate manner was weighted directly into separate digestion vessels, followed by the addition of about $7.0 \mathrm{~mL}$ of concentrated nitric acid $\left(\mathrm{HNO}_{3}\right)(65 \%)$ as well as $2.0 \mathrm{ml}$ of hydrogen peroxide $\left(\mathrm{H}_{2} \mathrm{O}_{2}\right)(30 \%)$. The combustion procedure was well optimized. The contents of the tubes were cooled then diluted to $50 \mathrm{~mL}$ with Deionized doubly distilled water, and also to be included with the samples during digestion and passed through the same dissolution procedures. Condition of digestion in microwave system was applied according to the study by Soylak et al.[22] and Waegeneers et al. [23].

\section{Statistical analysis}

For all of the analyzed elements, mean, median, and range were analyzed using the descriptive statistical analysis of Graph Pad Prism 7. Comparison between the two species and the impact of sex elements was analyzed using Student's $t$-test. Differences between groups were considered significant when $\mathrm{p}<0.05$. In 
addition, the values normal distribution was evaluated by D'Agostino and Pearson omnibus normality test.

\section{Results}

The results of serum trace element levels in horses and donkeys and their relation to gender are summarized in Tables- 1 and 2 and Figures-1-6. Significant differences between horses and donkeys were observed for three of the studied elements (Se, Mn, and Cr) (Figures-1-3), as serum Se and Mn levels were found to be higher in horses mean \pm standard error of mean $(45.27 \pm 1.29)$ and $(0.79 \pm 0.05)$, respectively, compared to that in donkeys which is $(33.83 \pm 1.71)$ and $(0.636 \pm 0.05)$, respectively. In contrast, the $\mathrm{Cr}$ level in horses $(1.80 \pm 0.3)$ was significantly lower than that in donkeys (4.73 \pm 0.594$)$. However, no statistically significant differences were observed

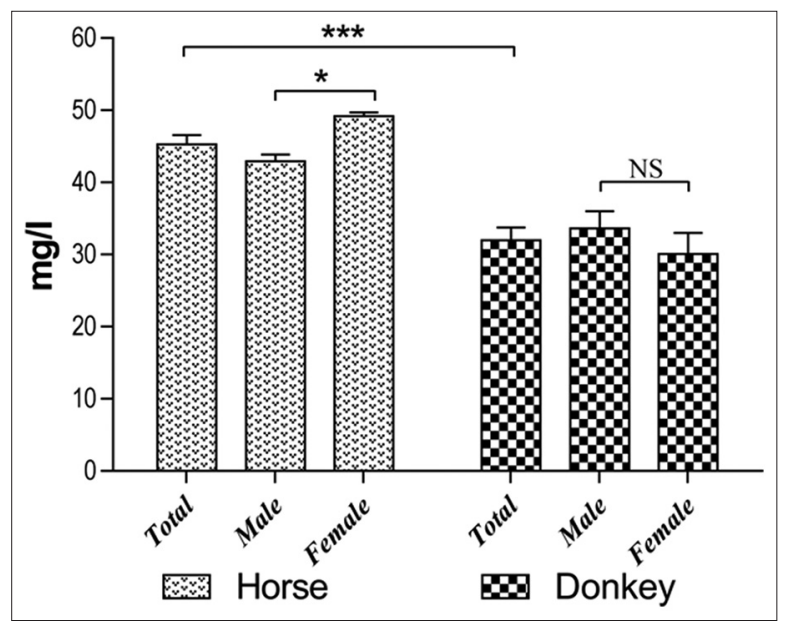

Figure-1: Concentrations $(\mathrm{mg} / \mathrm{l})$ selenium in serum of horses and donkeys. NS $>0.05, *<0.05$, and $* * *<0.001$.

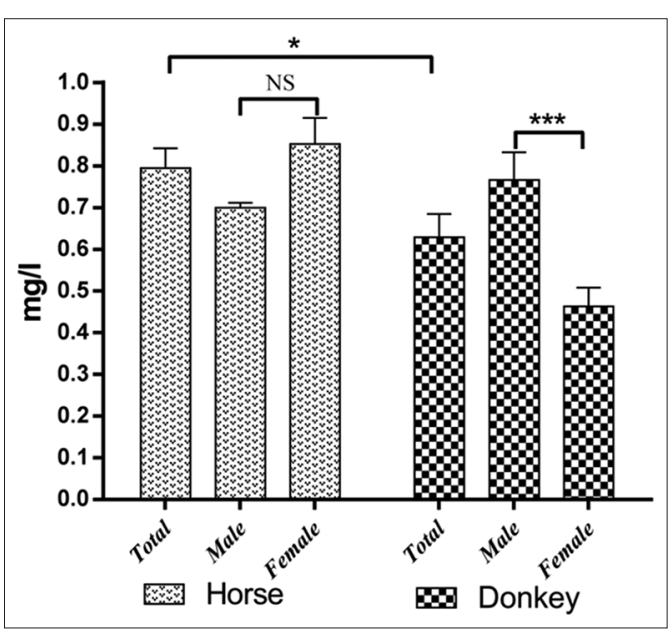

Figure-2: Concentrations $(\mathrm{mg} / \mathrm{l})$ manganese in serum of horses and donkeys. NS $>0.05, *<0.05$, and $* * *<0.001$.

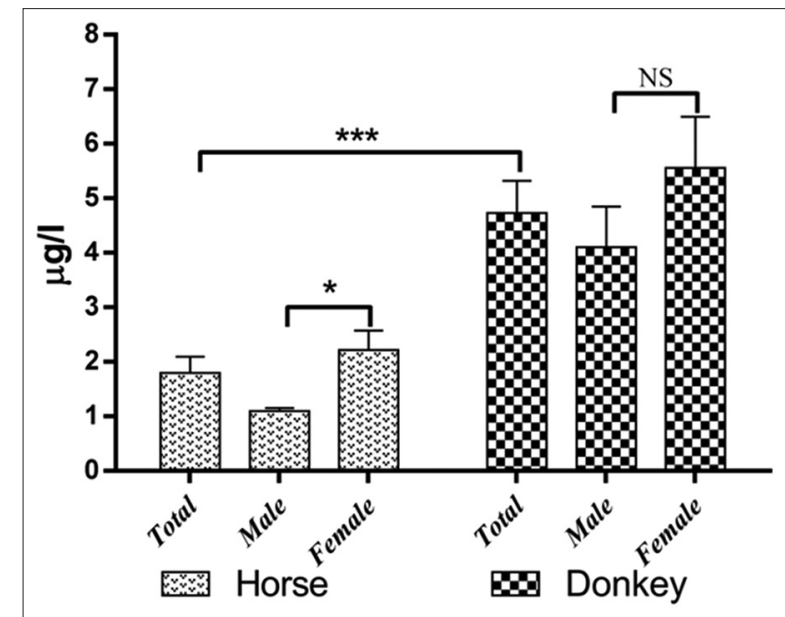

Figure-3: Concentrations $(\mathrm{mg} / \mathrm{l})$ chromium in serum of horses and donkeys. NS $>0.05$ and $* * *<0.001$.

Table-1: Descriptive statistics of trace elements concentration in Arabian horses and Hassawi Donkey.

\begin{tabular}{|c|c|c|c|c|c|c|}
\hline \multirow[t]{2}{*}{ Parameter } & \multicolumn{3}{|c|}{ Horse $(n=17)$} & \multicolumn{3}{|c|}{ Donkey $(n=28)$} \\
\hline & Mean \pm SEM & Median & Range & Mean \pm SEM & Median & Range \\
\hline $\mathrm{Se}(\mathrm{mg} / \mathrm{l})$ & $45.27 \pm 1.29$ & 44.7 & $41.31-49.12$ & $33.83 \pm 1.71$ & 33.67 & $30.42-35.12$ \\
\hline $\mathrm{Mn}(\mathrm{mg} / \mathrm{l})$ & $0.79 \pm 0.05$ & 0.74 & $0.66-0.98$ & $0.636 \pm 0.05$ & 0.57 & $0.36-0.95$ \\
\hline $\mathrm{Cr}(\mathrm{mg} / \mathrm{dl})$ & $1.80 \pm 0.3$ & 1.53 & $1.21-2.14$ & $4.73 \pm 0.594$ & 4.28 & $3.98-5.48$ \\
\hline $\mathrm{Cu}(\mathrm{mg} / \mathrm{l})$ & $1.28 \pm 0.185$ & 1.09 & $0.78-1.82$ & $1.61 \pm 0.426$ & 1.64 & $1.06-3.12$ \\
\hline $\mathrm{Fe}(\mathrm{mg} / \mathrm{l})$ & $7.1 \pm 1.73$ & 5.36 & $4.1-11.88$ & $4.95 \pm 0.711$ & 5.07 & $2.2-8.34$ \\
\hline $\mathrm{Zn}(\mathrm{mg} / \mathrm{l})$ & $0.11 \pm 0.006$ & 0.11 & $0.10-0.178$ & $0.104 \pm 0.05$ & 0.103 & $0.064-0.126$ \\
\hline
\end{tabular}

$\mathrm{Se}=$ Selenium, $\mathrm{Mn}=$ Manganese, $\mathrm{Cr}=$ Chromium, $\mathrm{Cu}=$ Copper, $\mathrm{Fe}=$ Iron, $\mathrm{Zn}=\mathrm{Zinc}, \mathrm{SEM}=$ Standard error of mean

Table-2: Mean and SEM of trace elements concentration in males and females in both of the Arabian horses and Hassawi Donkeys.

\begin{tabular}{|c|c|c|c|c|}
\hline \multirow[t]{2}{*}{ Parameter } & \multicolumn{2}{|c|}{ Horse (Mean \pm SEM) } & \multicolumn{2}{|c|}{ Donkey (Mean \pm SEM) } \\
\hline & Male $(n=7)$ & Female $(n=10)$ & Male $(n=12)$ & Female $(n=16)$ \\
\hline Se $(\mathrm{mg} / \mathrm{l})$ & $42.93 \pm 0.97$ & $49.19 \pm 0.55^{*}$ & $34.57 \pm 1.71$ & $30.09 \pm 2.96$ \\
\hline $\mathrm{Mn}(\mathrm{mg} / \mathrm{l})$ & $0.71 \pm 0.011$ & $0.85 \pm 0.06$ & $0.77 \pm 0.066$ & $0.463 \pm 0.04 * *$ \\
\hline $\mathrm{Cr}(\mathrm{mg} / \mathrm{l})$ & $1.1 \pm 0.057$ & $2.22 \pm 0.36 *$ & $4.10 \pm 0.75$ & $5.56 \pm 0.94$ \\
\hline $\mathrm{Cu}(\mathrm{mg} / \mathrm{l})$ & $0.91 \pm 0.067$ & $1.49 \pm 0.25$ & $2.17 \pm 0.69$ & $0.629 \pm 0.13 *$ \\
\hline $\mathrm{Fe}(\mathrm{mg} / \mathrm{l})$ & $5.25 \pm 0.66$ & $8.14 \pm 2.74$ & $4.46 \pm 0.80$ & $5.60 \pm 1.30$ \\
\hline $\mathrm{Zn}(\mathrm{mg} / \mathrm{l})$ & $0.147 \pm 0.054$ & $0.136 \pm 0.036$ & $0.115 \pm 0.004$ & $0.090 \pm 0.005^{* *}$ \\
\hline
\end{tabular}

$*<0.05, * *<0.01$. Se=Selenium, Mn=Manganese, $\mathrm{Cr}=$ Chromium, $\mathrm{Cu}=$ Copper, Fe=Iron, $\mathrm{Zn}=\mathrm{Zinc}$, SEM=Standard error of mean 
in serum concentrations of $\mathrm{Cu}, \mathrm{Fe}$, and $\mathrm{Zn}$ between horses and donkeys (Figures-4-6). Interestingly, the range of $\mathrm{Cu}$ level was wider in donkeys (1.06-3.12) than that in horses (0.78-1.82). As shown in Table-1, the median value of $\mathrm{Fe}$ and $\mathrm{Zn}$ levels was similar in horses (5.36 and 0.11 , respectively) and donkeys (5.07

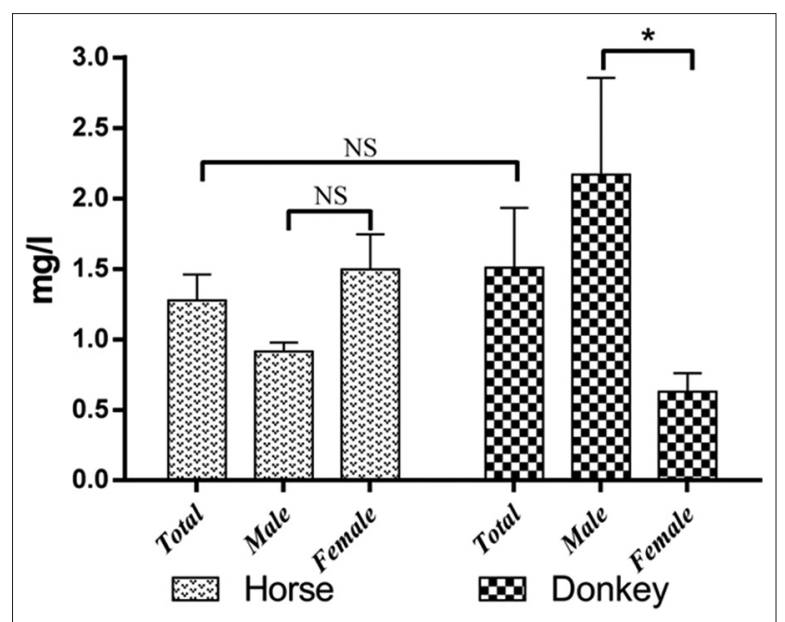

Figure-4: Concentrations $(\mathrm{mg} / \mathrm{l})$ copper in serum of horses and donkeys. NS $>0.05$ and $*<0.05$.

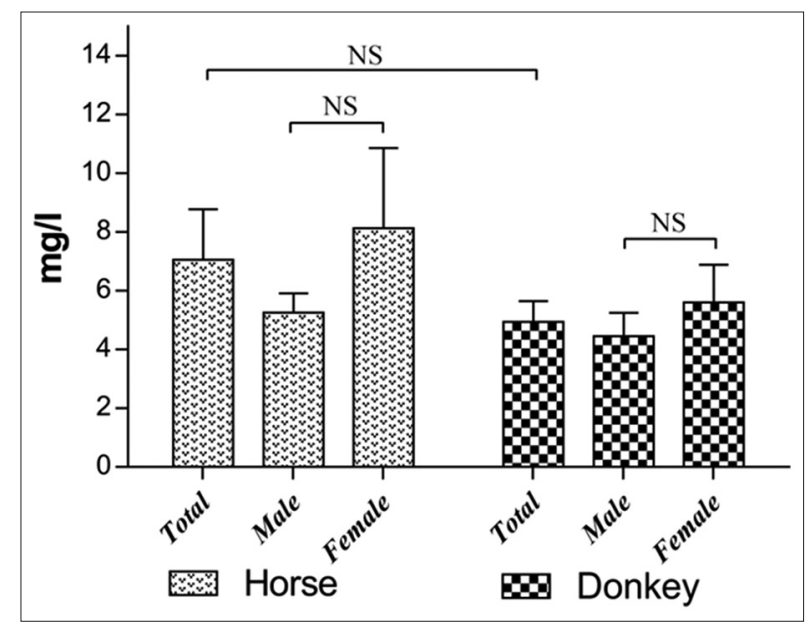

Figure-5: Concentrations $(\mathrm{mg} / \mathrm{l})$ iron in serum of horses and donkeys. NS $>0.05$.

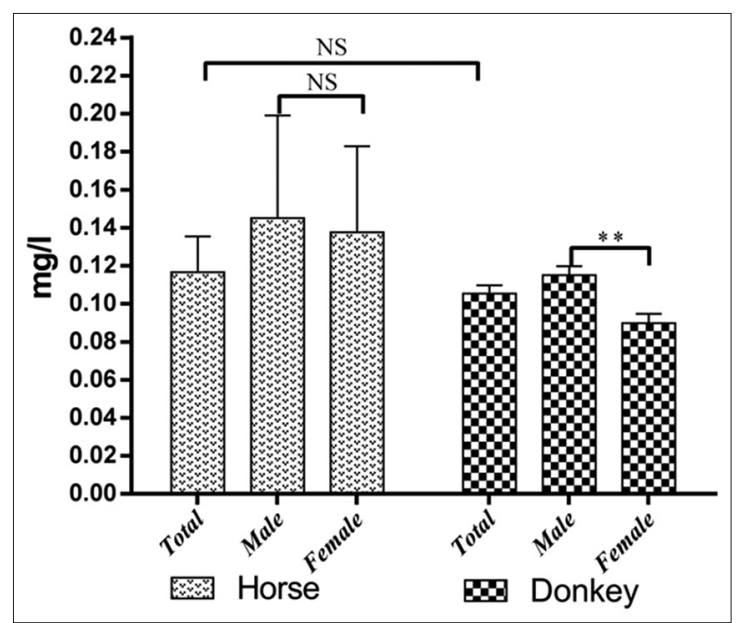

Figure-6: Concentrations $(\mathrm{mg} / \mathrm{l})$ zinc in serum of horses and donkeys. NS $>0.05$ and $* *<0.01$. and 0.103 , respectively). Statistically significant differences were found in serum $\mathrm{Se}$ and $\mathrm{Cr}$ between male and female horses, in which the concentrations were higher in female than that of male animals as shown in Table-2. When the serum trace elements concentration is compared between the male and female donkeys, male donkeys showed much higher $\mathrm{Mn}, \mathrm{Cu}$, and $\mathrm{Zn}$ levels than female animals as mentioned in Table-2 and Figures-2,4, and 6. Moreover, female donkeys shown higher levels of $\mathrm{Cr}$ and $\mathrm{Fe}$ compared to males, but this did not reach statistical significance (Table-2, Figures-3 and 5).

\section{Discussion}

Minerals play an essential role as structural components of the body and in the activities of the enzymes and hormones. They are also considered as important constituents of body fluids and tissues and as regulators of cell replication and its differentiation [1]. As only few literatures are available about the trace elements profile in donkeys and horses that are present in the eastern region of Saudi Arabia, this data can be considered as an important reference data, it also indicates the exposure factors of horses and donkeys to some specified elements that are present in the feed or the environment. In this study, the concentrations of trace elements were evaluated in Arabian horses and Hassawi donkey breed. However, the influence of both genders on the levels of trace elements in both species was also analyzed. The results were listed in Figures-1-6 and they were summarized in Tables-1 and 2. Serum is often used to detect the micro- and macro-elements because it reflects their content in the body $[7,8]$.

According to the obtained results that are listed in Table-1, the serum Se concentration was $45.27 \pm 1.29$ and $33.83 \pm 1.71$ in Arabian horses and Hassawi donkeys, respectively, which were much higher than the results that are reported by Muirhead et al. [24]. In this study, higher Se level was observed in horses when compared to that in donkeys which are agreed with the results reported by Richardson et al., who reported that Se levels in horses are 2.3 times more than that in donkeys serum [25]. The contrary of serum Se to other studies could be attributed to the level of dietary Se intake.

The measured Mn concentrations in donkeys and horses in the current study were more than the data reported for donkeys by Fantuz et al. [26] and that for horses by Okumura et al. [27]. Moreover, the obtained results of $\mathrm{Mn}$ for horses $(0.79 \pm 0.05)$ and donkeys $(0.636 \pm 0.05)$ were lower than the levels of Mn that are reported in camels by Sharkawy et al. [28] which is expected to be due to some factors such as species variations, environmental factors, and dietary factors.

The results of $\mathrm{Cr}$ levels in serum for donkeys and horses in the present study were slightly lower than that reported for human by Hasegawa et al. [29]. 
The results of $\mathrm{Cu}$ levels in serum for donkeys $(1.61 \pm 0.426)$ and horses $(1.28 \pm 0.185)$ in the present study were similar to the results reported for donkeys by Fantuz et al. [26] and the results for horses reported by Okumura et al. [27] and Maia et al. [30]. Interestingly, a significant higher level of $\mathrm{Cu}$ was found in stallion horses when compared to that of mares (Table-2). According to De Souza et al. [31], serum $\mathrm{Cu}$ concentrations can be affected by different areas and by the seasonal changes.

Our results did confirm the importance of high Fe levels in the Arabian horses $(7.1 \pm 1.73 \mathrm{mg} / \mathrm{l})$ and Hassawi donkeys $(4.95 \pm 0.71 \mathrm{mg} / \mathrm{l})$ than that in Turkman horses $(1.56 \mathrm{mg} / \mathrm{l})$ and Turkman donkeys $(1.4 \mathrm{mg} / \mathrm{l})$ reported by Zaeemi et al. [32]. No significant difference was observed in Fe level between the different genders in both of horses and donkeys (Table-2). Furthermore, similar results were previously reported by Dierenfeld et al. [33]. The different results of $\mathrm{Fe}$ levels in our study compared to other studies could be attributed to some factors such as breed variations, region, and dietary factors [33].

In our samples, serum $\mathrm{Zn}$ levels for donkeys were lower when compared to that reported by Fantuz et al. [26] and Zaeemi et al. [32]. De Souza et al. [31] reported a higher level of $\mathrm{Zn}$ in horses than the obtained results. The low concentrations of $\mathrm{Zn}$ in both Arabian horses and Hassawi donkeys can be attributed to insufficient mineral supplementation. Furthermore, some other factors can cause variations in $\mathrm{Zn}$ concentrations in horses which include environmental factors, dietary changes, and animal's physiology [34,35].

\section{Conclusion}

The obtained results of trace element levels in serum of Hassawi donkeys and Arabian horses in Saudi Arabia are considered as the first values to be published for these breeds. When compared to other animals, the measured amounts of $\mathrm{Se}, \mathrm{Mn}, \mathrm{Cr}, \mathrm{Cu}, \mathrm{Fe}$, and $\mathrm{Zn}$ in the serum of horses and donkey are often differed, possibly because of the varying living or feeding conditions. Moreover, there were some differences in some of the trace elements concentrations related to animal's gender and species (horses and donkeys), which will be considered in the interpretation of the laboratory data.

\section{Authors' Contributions}

TS participated in the fieldwork, the analysis of data and manuscript drafting, AM carried out the laboratory work and participated in manuscript drafting, WE and FA participated in the fieldwork and drafting of the manuscript, SA participated in the analysis of data, manuscript drafting and revision. All authors read and approved the final manuscript.

\section{Acknowledgments}

The researchers would like to thank the Veterinary Research Station, College of Veterinary Medicine,
King Faisal University, Saudi Arabia, as well as the laboratory unit at teaching hospital, College of Veterinary Medicine, King Faisal University, for their kind cooperation in conducting this valuable study. This research did not receive any specific grant from funding agencies in the public, commercial, or notfor-profit sectors.

\section{Competing Interests}

The author declares that they have no competing interests.

\section{References}

1. Balamurugan, B., Ramamoorthy, M., Ravi, J., Keerthana, G., Gopalakrishnan, K.M., Kharayat, S., Chaudhary, G.R. and Rahul, K. (2017) Mineral an important nutrient for efficient reproductive health in dairy cattle. Int. J. Environ. Sci. Technol., 6(1): 694-701.

2. Elrod, C.C., Van Amburgh, M. and Butler, W.R. (1993) Alterations of $\mathrm{pH}$ in response to increased dietary protein in cattle are unique to the uterus. J. Anim. Sci., 71(3): 702-706.

3. Topczewska, J. (2012) Effects of seasons on the concentration of selected trace elements in horse hair. J. Cent. Eur. Agric., 13(4): 671-680.

4. Humann-Zehank, E., Genter, M., Hennig-Pauka, I. and Binder, A. (2008) Trace mineral status and liver and blood parameters in sheep without mineral supply compared to local roe deer (Capreolus capreolus) populations. Small Rumin. Res., 75: 185-191.

5. Prashanth, L., Kattapagari, K.K., Chitturi, R., Baddam, V. and Prasad, L. (2015) A review on role of essential trace elements in health and disease. J. NTR Univ. Health Sci., 4(2): 75-78.

6. Laven, R.A., Livesey, C.T., Harmon, R.J. and Scaletti, R. (2006) Factors affecting the relationship between caeruloplasmin activity and plasma copper concentration in cattle. Vet. Rec., 159(8): 250-251.

7. Forrer, R., Wenker, C.H., Gautschi, K. and Lutz, H. (2001) Concentration of 17 trace elements in serum and whole blood of plains viscachas (Lagostomus maximus) by ICP-MS, their reference ranges, and their relation to cataract. Biol. Trace Elem. Res., 81(1): 47-62.

8. Stanek, M., Jaworski, Z., Sobotka, W., Lipiński, K. and Olenkowicz, R. (2016) Influence of an organic supplement of copper, zinc and manganese in feed rations on concentrationsof these elements in the coat of Polish Konik horses. J. Elem., 21(2): 549-558.

9. Ciftci, T.U., Ciftci, B., Yis, O., Guney, Y., Bilgihan, A. and Ogretensoy, M. (2003) Changes in serum selenium, copper, zinc levels and cu/zn ratio in patients with pulmonary tuberculosis during therapy. Biol. Trace. Elem. Res., 95(1): 65-71.

10. Nève, J. and Palmieri, P. (2000) First symposium on human health related aspects of selenium research in Europe. J. Trace Elem. Med. Biol., 14: 116-121.

11. Cefalu, W.T. and Hu, F.B. (2004) Role of chromium in human health and in diabetes. Diabetes Care, 27(11): 2741-2751.

12. Schuschke, D.A. (1997) Dietary copper in the physiology of the microcirculation. J. Nutr., 127(12): 2274-2281.

13. Maggini, S., Wintergerst, E.S., Beveridge, S. and Hornig, D.H. (2007) Selected vitamins and trace elements support immune function by strengthening epithelial barriers and cellular and humoral immune responses. Br. J. Nutr., 98: S29-S35.

14. Oppenheimer, S.J. (2001) Iron and its relation to immunity and infectious disease. J. Nutr., 131: 616S-635S.

15. Hambidge, M. (2000) Human zinc deficiency. J. Nutr., 130 5S Suppl: 1344S-1349S. 
16. Caulfield, L.E., Zavaleta, N. and Figueroa, A. (1999) Adding zinc to prenatal iron and folate supplements improves maternal and neonatal zinc status in a Peruvian population. Am. J. Clin. Nutr., 69(6): 1257-1263.

17. Fraker, P.J., King, L.E., Lakkko, T. and Vollmer, T.L. (2000) The dynamic link between the integrity of the immune system and zinc status. J. Nutr., 130 5S Suppl: 1399S-1406S.

18. Shawaf, T., Almathen, F., Al-Ahmad, J. and Elmoslemany, A. (2016) Morphological characteristics of hassawi donkey, eastern province, Saudi Arabia. Alex. J. Vet. Sci., 49: 178-183.

19. Passlack, N., Mainzer, B., Lahrssen-Wiederholt, M., Schafft, H., Palavinskas, R., Breithaupt, A. and Zentek, J. (2015) Concentrations of strontium, barium, cadmium, copper, zinc, manganese, chromium, antimony, selenium, and lead in the liver and kidneys of dogs according to age, gender, and the occurrence of chronic kidney disease. J. Vet. Sci., 16(1): 57-66.

20. Al-Bulushi, S., Shawaf, T. and Al-Hasani, A. (2017) Some hematological and biochemical parameters of different goat breeds in Sultanate of Oman "a preliminary study". Vet. World, 10(4): 461-466.

21. Roubies, N., Panousis, N., Fytianou, A., Katsoulos, P.D., Giadinis, N. and Karatzias, H. (2006) Effects of age and reproductive stage on certain serum biochemical parameters of chios sheep under greek rearing conditions. J. Vet. Med. A Physiol. Pathol. Clin. Med., 53(6): 277-281.

22. Soylak, M., Saracoglu, S., Tuzen, M. and Mendil, D. (2005) Determination of trace metals in mushroom samples from Kayseri Turkey. Food Chem., 82: 649-652.

23. Waegeneers, N., Pizzolon, J.C., Hoenig, M. and De Temmerman, L. (2009) Accumulation of trace elements in cattle from rural and industrial areas in Belgium. Food Addit. Contam., 26(3): 326-332.

24. Muirhead, T., Wichtel, J., Stryhn, H. and McClure, J. (2010) The selenium and Vitamin E status of horses in Prince Edward Island. Can. Vet. J., 51: 979-985.

25. Richardson, S.M., Siciliano, P.D., Engle, T.E., Larson, C.K. and Ward, T.L. (2006) Effect of selenium supplementation and source on the selenium status of horses. J. Anim. Sci., 84(7): 1742-1748.
26. Fantuz, F., Ferraro, S., Todini, L., Mariani, P., Piloni, R. and Salimei, E. (2013) Essential trace elements in milk and blood serum of lactating donkeys as affected by lactation stage and dietary supplementation with trace elements. Animal, 7(11): 1893-1899.

27. Okumura, M., Asano, M., Tagami, M., Tsukiyama, K. and Fujinaga, T. (1998) Serum copper and ceruloplasmin activity at the early growing stage in foals. Can. J. Vet. Res., 62(2): 122-126.

28. Sharkawy, A.A., Rateb, H.Z. and Abdel-Mohsen, M. (2002) Evaluation of some heavy metals in blood and tissues of male camels as indicator of environmental pollution and its relation to age. Assuit Univ. Bull. Environ. Res., 5: 73-81.

29. Hasegawa, M., Yoshida, K., Wakabayashi, H. and Sudo, A. (2012) Cobalt and chromium ion release after large-diameter metal-on-metal total hip arthroplasty. J. Arthroplasty, 27(6): 990-996.

30. Maia, L., Souza, M.V., Fernandes, R.B.A., Fontes, M.P.F., Viana, M.W.S. and Luz, W.V. (2006) Heavy metals in the horse blood, serum, and feed in Minas Gerais. J. Equine Vet. Sci., 26: 578-583.

31. De Souza, M., Paulo, M., Fontes, F., Bragança, R. and Fernandes, A. (2014b) Heavy metals in equine biological components. R. Bras. Zootec., 43(2): 60-66.

32. Zaeemi, M., Razmi, G.R., Mohammadi, G.R., Abedi, V. and Yaghfoori, S. (2016) Evaluation of serum biochemical profile in Turkoman horses and donkeys infected with Theileria equi. Rev. Méd. Vét., 167(11-12): 301-309.

33. Dierenfeld, S., Shirley,A. N., Craig, A., Karen, C., Walker, W., Jurgen, S. and Marcus, C. (2005) Mineral concentrations in serum/plasma and liver tissue of captive and free-ranging Rhinoceros Species. Zoo Biol., 24: 51-72.

34. Auer, D.E., Ng, J.C. and Seawright, A.A. (1988) Assessment of copper and zinc status of farm horses and training Thoroughbreds in South-East Queensland. Aust. Vet. J., 65: 317-320.

35. Birick, H., Ocal, N., Gucus, A.I., Ediz, B. and Uzman, M. (2005) Seasonal changes of some mineral status in mares. $J$. Equine Vet. Sci., 25: 346-348. 